\title{
Revision of Hycleus solonicus (Pallas, 1782) (Coleoptera: Meloidae, Mylabrini), with larval description and DNA barcoding
}

\author{
Zhao Pan, Qian-Qian Bai, Jue Wang \& Guo-Dong Ren
}

\begin{abstract}
Pan, Z., Bai Q.-Q., Wang, J. \& Ren, G.-D. 2017: Revision of Hycleus solonicus (Pallas, 1782) (Coleoptera: Meloidae, Mylabrini), with larval description and DNA barcoding. - Entomol. Fennica 28: 219-232.

Hycleus solonicus (Pallas, 1782), referred to H. polymorphus species group, is revised. Adults are redescribed and illustrated, eggs and first-instar larvae are described and illustrated for the first time, COI sequence for DNA barcoding is reported for the first time, the geographical distribution is revised and all available faunistic records from the literature and collections are summarized. In addition, two incorrect determinations are pointed out and Zonabris solonica var. dianae Sahlberg, 1913 is proposed to be a synonym of Hycleus scabiosae (Olivier, 1811).
\end{abstract}

Z. Pan, The Key Laboratory of Zoological Systematics and Application, College of Life Sciences, Hebei University, Baoding, Hebei 071002, P. R. China; E-mail: panzhao86@yeah.net

Q.-Q. Bai, The Key Laboratory of Zoological Systematics and Application, College of Life Sciences, Hebei University, Baoding, Hebei 071002, P. R. China

J. Wang, College of Life Sciences, Hebei University, Baoding, Hebei 071002, P. R. China

G.-D. Ren, The Key Laboratory of Zoological Systematics and Application, College of Life Sciences, Hebei University, Baoding, Hebei 071002, P. R. China; Email:gdren@hbu.edu.cn.

Received 30 August 2016, accepted 22 December 2016

\section{Introduction}

Hycleus Latreille, 1817, belonging to the tribe Mylabrini, is the most speciose genus of the blister beetle family (Meloidae) with approximately 430 described species. The genus is restricted to the Old World and centered in the Afrotropical region (Bologna \& Pinto 2002). However, the only study of the genus is a very old comprehensive monograph (Marseul 1872) devoted to the entire tribe Mylabrini. Hycleus itself remains inadequately studied and needs to be completely re- vised. In the literature it has been confused with the genus Mylabris Fabricius, 1775 and other Mylabrini genera by several authors. The very complex synonymy and generic definition of Hycleus were explained by Bologna $(1978,1991)$ and Bologna and Pinto (2002).

The taxonomy of some species or species groups has been studied in the last 50 years (e.g. Pardo Alcaide 1954, 1955, 1958, 1968, Saha 1972, 1979, Bologna 1978, 1979, 1990, 1991, Bologna \& Turco 2007). Recently, a preliminary taxonomic study of Chinese Hycleus species was 


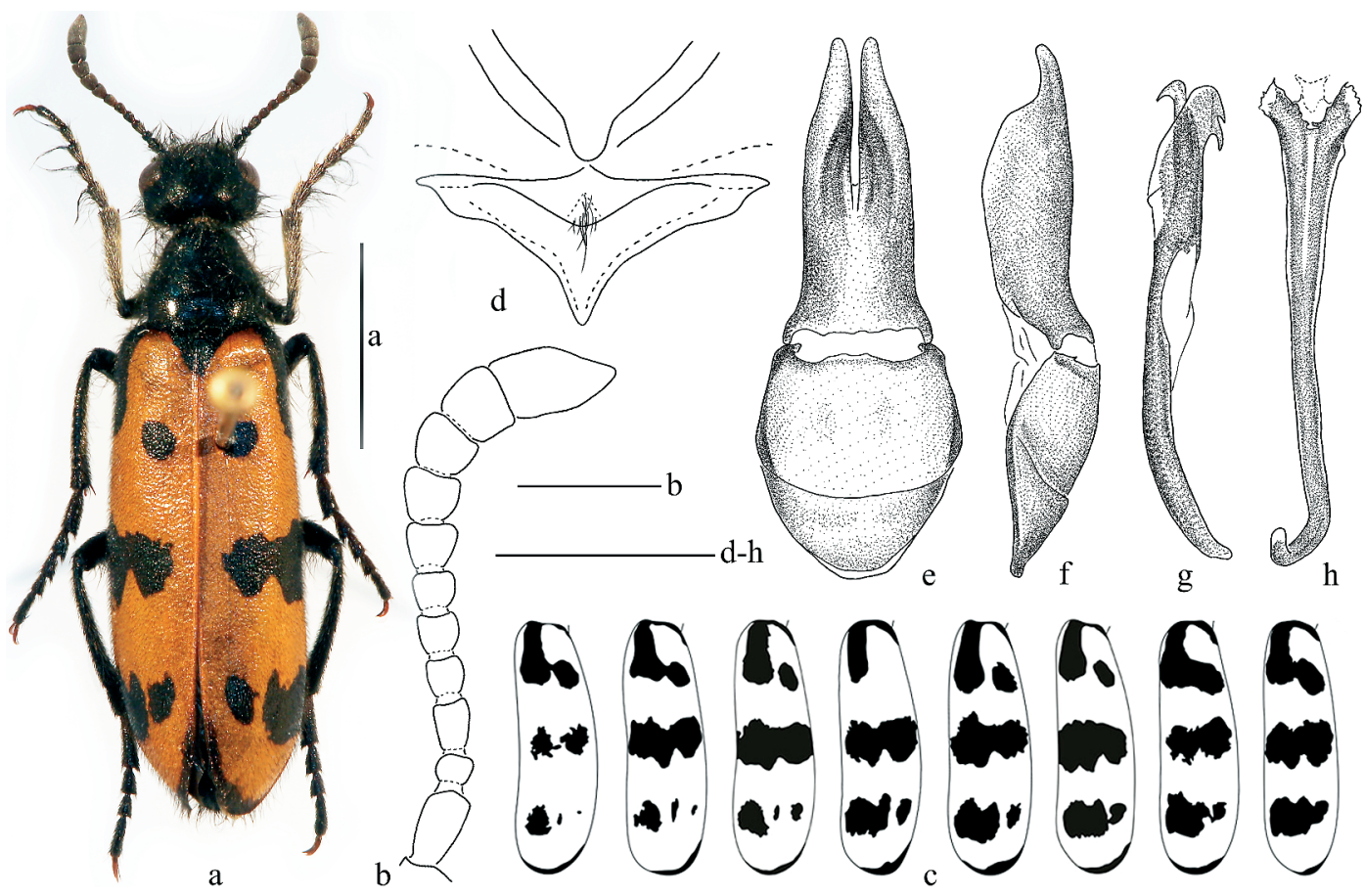

Fig. 1. Hycleus solonicus (Pallas, 1782), adult. - a. Habitus, male. - b. Antenna, male. - c. Elytral patterns, both sexes. $-d$. Mesosternum and mesepisterna, male. $-\mathrm{e}$. Tegmen, male, ventral view. $-\mathrm{f}$. Tegmen, male, lateral view. - g. Aedeagus, male, lateral view. - h. Spiculum gastrale, male. Scale bars: $5 \mathrm{~mm}(\mathrm{a}) ; 1 \mathrm{~mm}$ (b, d-h).

published by Pan et al. (2011a), and a key of the Oriental phaleratus species group from China has been published by Pan et al. (2014).

Hycleus polymorphus species group belongs to the Hycleus lineage characterized by a mesosternum of Mesoscutatus type (see Bologna, 1991). It is widely distributed in the Palaearctic region. It is easily distinguishable from other Hycleus groups belonging to the Mesoscutatus lineage by the following characters: antennae black, with 11 antennomeres; antennomeres VIIIX widened (Fig. 1b); elytra black with some reddish yellow spots and fasciae: two basal spots (one in the middle, and one on the external margin but disappeared in some species), two middle transverse fasciae and one apical spot; the yellow spots and fasciae enlarged and fused in some species (Fig. 1c). The polymorphus group includes at least 13 species: H. atratus (Pallas, 1773), H. biguttatus (Gebler, 1841), H. chodschenticus (Ballion, 1878), H. fuscus (Olivier, 1811), H. humerosus (Escherich, 1899), H. pierrei (Kaszab, 1969), H. polymorphus (Pallas, 1771), H. quatu- ordecimpunctatus (Pallas, 1782), H. scabiosae (Olivier, 1811), H. solonicus (Pallas, 1782), H. tekkensis (Heyden, 1883), H. tenerus (Germar, 1834), and H. zebraeus (Marseul, 1870).

Hycleus solonicus (Pallas) occurs very commonly in the northeastern Palaearctic region, especially in the far western Chinese region east of Mt. Altai. It lacks detailed descriptions or character illustrations before the present study. When one of the authors (Pan) working on specimens of Chinese meloid species housed in the M. Bologna's collection (MAB), he recognized that $H$. solonicus was wrongly determined as Mylabris axillaris and $H$. chodschenticus by both Tan (1986) and Pan et al. (2010), which led to interpretate erroneously the distribution of the species, especially in China.

The morphology of first-instar larvae (also called triungulins) of the genus Hycleus has been scarcely dealt (e.g. Beauregard 1890, MacSwain 1956), but some species have been utilized for phylogenetic studies (Bologna \& Pinto 2001). In addition, two studies on triungulins of the genus 
Mylabris from the former USSR (Juchnevitsch 1955, Priamikova \& Juchnevitsh 1958) referred to six species of the polymorphus group $(H$. atratus, $H$. biguttatus, $H$. chodschenticus, $H$. polymorphus, $H$. scabiosae, and $H$. tekkensis). However, the triungulins of $H$. solonicus has never been studied.

The main purposes of this study are to redescribe the adult of Hycleus solonicus, to provide its $\mathrm{COI}$ sequence fragment for DNA barcoding for the first time, to review its geographical distribution, and to describe the morphology of the egg and the first-instar larva.

\section{Materials and methods}

Totally 1,438 adult specimens of the species were examined for this study, including 1,405 from China and 33 from Mongolia. The following abbreviations used in the text represent the studied collections:

IZCAS $=$ Chinese Academy of Sciences, Institute of Zoology, Beijing, China

$\mathrm{MAB}=\mathrm{M}$. A. Bologna coll., Università degli studi Roma Tre, Rome, Italy

MHBU (and MHBUa) = Museum of Hebei University, Baoding, China (the material preserved in $95 \%$ alcohol $=$ MHBUa)

$\mathrm{MZH}=$ Finnish Museum of Natural History, University of Helsinki, Helsinki, Finland

NKUM = Nankai University, Tianjin, China

NXUM = Ningxia University, Yinchuan, China

$\mathrm{TMNH}=$ Tianjin Museum of Natural History, Tianjin, China

ZIN = Russian Academy of Sciences, Zoological Institute, St. Petersburg, Russia

The figures of the morphological details were drawn by hand, using a Nikon SMZ1500 stereomicroscope equipped with a camera lucida. The photographs of adult habitus were taken with a Canon EOS 5D Mark III connected to a Canon Macro lens EF $100 \mathrm{~mm}$.

The first-instar larvae of $H$. solonicus, used for the description, were held at a room-temperature on 7.VII.2014. The eggs were laid from adults that were collected on 3.VII.2014 from Jinhekou of Mt. Xiaowutaishan (Yu County, Hebei Prov., China) by Zhi-Zhong Gao.
Table 1. GenBank accession numbers of COI sequences of the species used as comparisons with Hycleus solonicus.

\begin{tabular}{lcc}
\hline Species & Length (bp) & Source \\
\hline Hycleus chodschenticus & 704 & JX679716 \\
Hycleus phaleratus & 713 & KC112991 \\
Hycleus cichorii (unverified) & 778 & KC112989 \\
Hycleus parvulus (unverified) & 741 & JX861893 \\
\hline
\end{tabular}

The larvae were observed and described using a Olympus BX53 microscope, photographs were taken by using the desktop SEM Hitachi TM3000.

The methods of the molecular studies are the same as those used in Liu et al. (2016), but the genetic distances were calculated by using the Kimura 2-parameter model (K2P, Kimura 1980). The samples used for DNA barcodes are listed in detail in the Appendix I and deposited in MHBUa. The four other COI sequences (Table 1), i.e. those of $H$. chodschenticus, H. phaleratus, $H$. cichorii, and $H$. parvulus, were downloaded from GenBank and used to calculate the interspecific genetic distances in the genus Hycleus.

\section{Hycleus solonicus (Pallas, 1782)}

Meloe solonica Pallas, 1782: 87, fig. E-12 (Type locality: "Rossiae Sibiriaeque" = Siberia of Russia. Type depository: ZIN, but destroyed by fire); Billberg 1813: 74 .

Mylabris solonica: Schönherr 1817: 35; Fischer 1827: 7; Waltl 1838: 465; Reiche 1866: 636; Gemminger \& Harold 1870: 2143; Marseul 1870: 89; 1872: 510; Oertzen 1886: 264; Sumakov 1915: 38; 1930: 67; Reichardt 1934: 232; Kôno 1940: 57; IablokoffKhnzorian 1983: 69.

Mylabris famelica Ménétriés, 1854: 36 (Type locality: China. Type depository: ZIN); Gemminger \& Harold 1870: 2137. Synonymized by Sumakov 1930: 67.

Zonabris solonica: Heyden 1881: 152; 1893: 131; Escherich 1892: 124; 1899: 91; Dokhtouroff 1889: 159.

Mylabris (Tigrabris) solonica: Kuzin 1954: 365. 
Mylabris axillaris: Tan 1986: 486, fig. 11-15-5; Ma et al. 1991: 148; Guo 1994: 22; Tan et al. 1995: 325; Hua 2002: 130; Yang \& Ren 2007: 430, fig. 17 (hing wing). [nec. Billberg, 1813] Mylabris (Mylabris) solonica: Tshernyshev \& Axentiev 1996: 54.

Hycleus solonicus: Bologna 2008: 389.

Hycleus chodschenticus: Pan et al. 2010: 185; 2011a: 182, fig. 4, 19; 2011b: 730, fig. 9; 2013: 214; Ren \& Niu 2011: 137, fig. 10 (hing wing); Zhao et al. 2012: 37. [nec. Ballion, 1878]

\subsection{Descriptions}

\subsubsection{Adult}

Diagnosis. A species of the Mesoscutatus type lineage, belonging to the polymorphus group. Body only with black setae except ventral side of prothorax, elytral axillary part, all coxae, pro- and mesotibiae and protarsi with mixed black and yellow setae at least. Basal part of antennomere XI approximately as wide as the apical part of antennomere X (Fig. 1b). Elytral yellow-reddish fasciae wide and various (Fig. 1c). Fore margins of mesepisterna forming a median wide groove; "scutum" (see Bologna \& Pinto 2002) wide, with dense long setae on posterior central part (Fig. 1d). Setae on external side of protibiae and protarsomeres I-IV conspicuously longer than those on other parts of tibia and tarsi in male. Parameres (Figs 1e, f) with slender and elongate apical lobes, much narrower than basal two-third in ventral view. Distal aedeagal dorsal hook positioned in the middle between proximal hook and apex; proximal hook slender (Fig. 1g).

The elytral pattern of adult Hycleus solonicus is very similar to $H$. quatuordecimpunctatus, $H$. chodschenticus, H. scabiosae, and H. humerosus. However, $H$. solonicus can be easily distinguished from the latter four species by: 1) $\mathrm{Hy}$ cleus solonicus has no yellow setation on pronotum and dorsal surface of head, while the latter four species have mixed yellow and black setae on pronotum and dorsal surface of head. 2) The body length is $15-22 \mathrm{~mm}$, while the latter four species are usually shorter than $15 \mathrm{~mm}$. 3) The shape of their mesosternal "scutum" is different as well as the length and density of apical setae on the "scutum". 4) The setae on pronotum and male protarsomeres are longer than those of the four species. 5) The shape of head and pronotum, and the density of punctures on head and pronotum are different. 6) The position and shape of male aedeagal distal hook are different among these five species.

Redescription. Body (Fig. 1a) unicolour black, except anterior margin of clypeus dark red, apex of mentum brownish yellow, antennomeres III-XI brown-black, and elytra black but with yellow spots and fasciae as in Fig. 1c. Body with black long setae, except antennomeres III-XI and legs only with long setae on ventral sides of all coxae, trochanter, femora, and external sides of protibiae and protarsomere I-IV (male) or I-III (female, and evidently shorter and fewer than male), but mixed golden setae on following parts: ventral side of thorax, elytral axillary part, prolegs, mesolegs except tarsi, ventral side of metatibiae, and tarsal pads; sometimes lacking yellow setae on ventral side of meso- and metathorax, all femora, and metatibiae. Body length (apex of mandibles-apex of elytra): 15-22 mm.

Head: Subquadrate, evidently wider than long (from fronto-clypeal suture to posterior margin of head), with maximum width at level of eyes. Punctures shallow, medium in size and quite dense, distance between punctures less than their diameter, with a longitudinal impunctate area on center of frons. Eye globose, with antero-dorsal margin slightly sinuate, just behind antennal insertion. Temple slightly widened, subparallel, only slightly curved posteriad and slightly shorter than longitudinal diameter of eye. Clypeus narrower than interocular width, rounded on sides, posteriorly with similar punctures as on frons, anteriorly almost smooth and slightly sloping; labrum scarcely narrower than clypeus, rounded on sides, fore margin almost straight in both sexes, medially slightly depressed. Maxillary galeae and palpomeres unmodified in both sexes. Mandibles curved and progressively narrowed on apical half. Antennae with 11 antennomeres (Fig. 1b), subopaque; antennomere I approximately as long as II-III together; II subglobose; III-IV subcylindrical and slender, III slightly longer than IV; IV-VI similar in length; VII slightly longer than VI; VIII and IX with similar length, 
subtrapezoidal, apically enlarged on external side, increasing in width from $\mathrm{V}$ to $\mathrm{X}$ and then decreasing from $\mathrm{X}$ to $\mathrm{XI}, \mathrm{X}$ subquadrate and slightly longer than IX; XI conspicuously narrower and nearly twice as long as $\mathrm{X}$, subcylindrical but narrowed in the apical two-fifth.

Thorax: Pronotum slightly wider than long, about as wide as head at temple, widest in middle, slightly rounded and subparallel on sides of basal half, and then conspicuously narrowing anteriad; fore portion slightly depressed, as well as on middle of base, just in front of mesonotum, three slight depressions transversely on center; punctures similar to those on head, with a longitudinal medial small furrow, almost impunctate. Elytral pattern as in Fig. 1a, c. Mesosternum of mesoscutatus-type (Fig. 1e); apex of "scutum" densely covered with long black setae; fore margins of mesepisterna forming a wide median groove. Legs slender; protibiae with two spurs, both tibial spurs on all legs slender; protarsi in both sexes with a distinct golden ventral pad. Protarsi longer than protibiae, protarsomeres always longer than wide, slightly widened apically and with dense and longer setae at apex of I-IV in male but I-III in female. Long setae on external side of protibiae and protarsomeres conspicuously longer in male than in female

Abdomen: Posterior margin of penultimate male abdominal sternite subrectilinear, that of last visible sternite emarginated. Parameres (Fig. 1e, f) conspicuously elongate in ventral view, their length approximately 1.3 times length of phallobase; divided from middle; with slender and elongate apical lobes, much narrower than basal twothirds.

Aedeagus: With two hooks, distal one smaller than proximal one, with different shape, and positioned in middle between proximal hook and apex (Fig. 1g); endophallic hook large. Spiculum gastrale as in Fig. $1 \mathrm{~h}$.

\subsection{2. $\mathrm{Egg}$}

Description. Egg white, elongate, round at both ends, a little wider at one apex, and length/maximal width approximately $2.03 / 0.58 \mathrm{~mm}$.

\subsubsection{First-instar larva}

Diagnosis. Head slightly narrower than anterior part of pronotum; basal elevation absent; palpomere MX2 twice as long as MX1, MX3 three times as long as MX2; ecdysial line present on pro- and mesonotum and absent on metanotum.

According to the key published by Priamikova and Juchnevitsh (1958), the first-instar larvae of $H$. solonicus could be easily distinguished from the other species of the polymorphus group, except $H$. chodschenticus, by the mesonotum having eight setae on PR. The first-instar larva of $H$. solonicus is very similar to that of $H$. chodschenticus, however, and we could not find any differences between them based on the description made by Juchnevitsh (1955). Before the first instar larvae of these two species can be separated, a detailed description is needed also for $H$. chodschenticus in addition to the description below for $H$. solonicus.

Description. Habitus (Fig. 2a, b) and microsculpture: triungulin elongate, about 3.74 times as long as greatest width (on meso-metathorax), evenly narrowed posteriorly. Head, legs, terga and abdominal sterna well sclerotised. Colour light-brown. Cuticle of sclerotized areas of body with irregular polygonal meshes, meshes very sparse on head, pro-, meso-, and metanotum.

Head (Figs 2c, d): Cephalic capsule transverse, sub-rectangular, widest at base, sub-parallel on sides; dorsal surface regularly convex, with truncate anterior margin and without basal elevation. Epicranial suture visible, stem short, frontal arms almost reaching antennal base. Single stemma present on each side, border almost invisible. Frons fused to clypeus without apparent suture; labrum and anterolateral sides of frontoclypeus folded ventrally, fitting host seta, and partially covering mandibles. Frontoclypeal row (FCR) with three pairs of setae, lateralmost (FCR3) nearly ventral due to folding of anterolateral frontoclypeus, sub-equal to length of FCR2; FCR1 much shorter than others; sensory pit absent. Four pairs of setae posterior to FCR, following a curved line paralleling arms of epicranial suture; lateralmost longest, slightly anterior to antennal insertion. Each epicranial plate with one seta posterior of antennal fossa; ocular seta unmodified, much longer than others, placed 

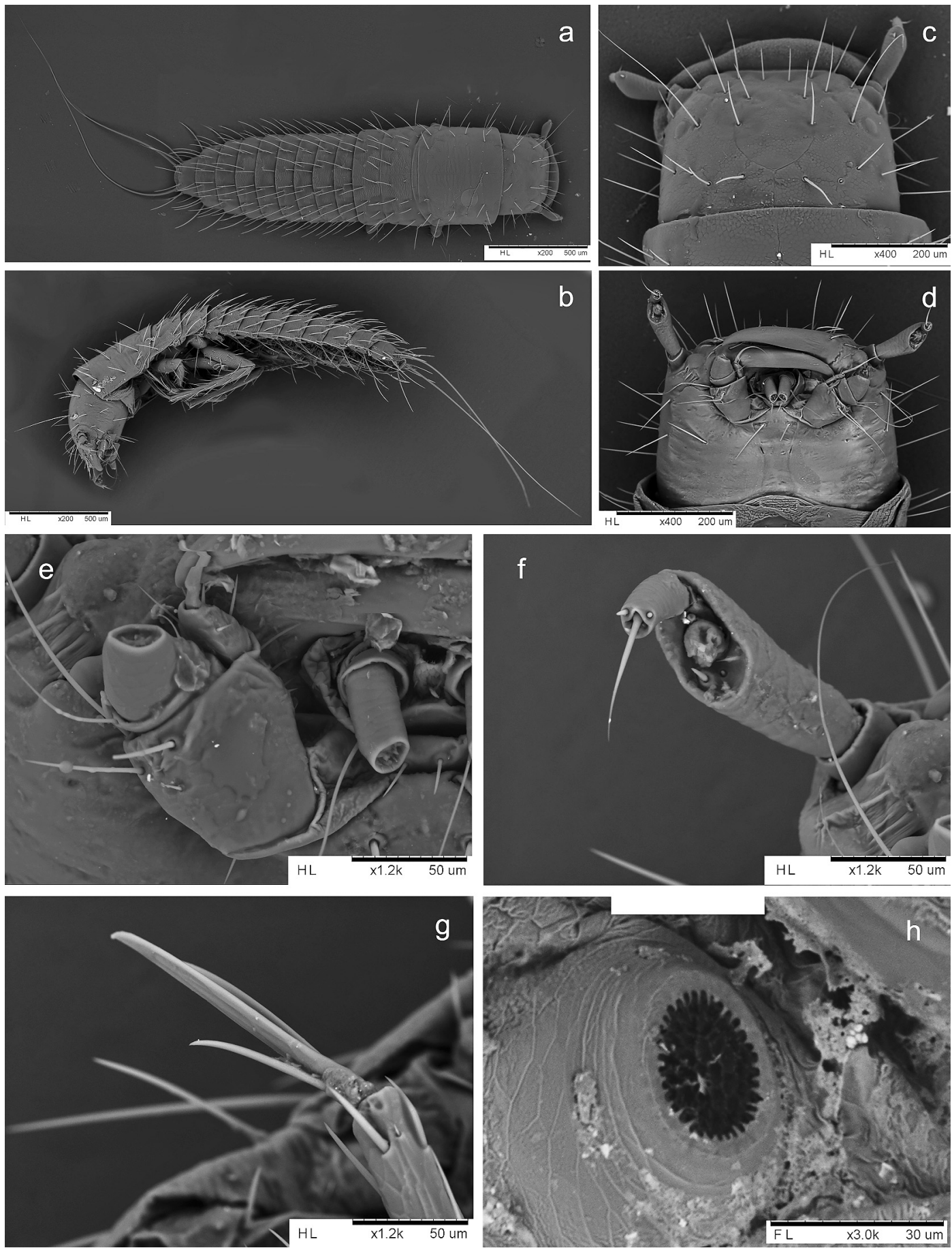

Fig. 2. Hycleus solonicus (Pallas, 1782), first-instar larva. - a. Habitus, dorsal view. - b. Habitus, ventral view. - c. Head, dorsal view. - d. Head, ventral view. - e. Mouthparts, frontal view. -f. Right antenna, ventral view. - g. Metathoracic claw. - h. Mesothoracic spiracle. 
anterior to stemmata and posterior to ocular sensory pit; four pairs of setae dorsally anterior to base, one pair of large pits displaced anteriorly of medial pair; three pairs of setae longitudinally arranged on sides. Labrum transverse, almost covered by clypeus, with straight anterior margin, with three pairs of setae of different sizes approximately distributed along margin, and other two setae on center. Mandibles ventral in position, falcate (Fig. 2d); cutting edge smooth; lateral margin with two setae on basal half and two pits mesodorsally. Maxillae (Fig. 2e) with stipes very broad, with two rows of setae: apical row (first row) with three setae, lateral seta extremely long, medial seta short; basal row (second row) with single short setae and one pit; cardo transverse, cardinal seta present; mala simple, lobiform, protruding, with several long thick setae; maxillary palpi short, slightly longer than stipe, threejointed: palpomere I short, II twice as long as I, III approximately three times as long as II, with a large apical sensory area bearing a crown of approximately seven conical papillae and a medial conspicuous sticklike sensory papilla longer than others; segment I with one ventral pit; palpomere II with two lateral setae, outer one very long, subequal to length of stipe, and inner one extremely short; palpomere III asymmetric, subhemispherical, with one short seta on inner side and one slender, elongate, lateral digitiform sensillum. Labium with mentum bearing one pair of short setae basally; submentum with one pair of setae positioned subapically and one pit in middle; prementum with one pair of medial setae near insertions of palpi on prementum and one pair of minute setae at base; labial palpomere I short and broad, labial palpi small (Fig. 2e) with joints very short, cylindrical; II cylindrical, slightly more than twice I, with a small apical sensory appendix surrounded by eight smaller papillae, one sensory pit lateroventrally (outer side). Antennae (Fig. 2f) short, anterolaterally directed; antennomere I short, ring-like, with one dorsal and one lateral sensory pit; antennomere II subcylindrical, about four times as long as I, asymmetrical with two short spinelike apical setae (one dorsolateral, one ventral), and one dorsal pit; sensory appendix on second joint reduced to a disklike plate laying obliquely at ventrolateral apex; antennomere III slender, cylindrical, about half as long as II, with a long apical seta (antennal seta) slightly shorter than antennomere III, and three short subapical spine-like setae and one minute seta, also with one basolateral pit.

Thorax (Fig. 2a): Segments transverse, slightly broader than head, with terga well sclerotized, subequal in width; pronotum subsquare with sides straight but slightly enlarged at base; meso- and metanotum subrectangular, their total length approximately 0.7 times of that of pronotum, with sides straight; metanotum slightly shorter than mesonotum and similar in width. Ecdysial line well marked and complete on proand mesonotum but absent on metanotum. Pronotum with 20 setae ( 15 long and five short) and six pits present symmetrically at each side of ecdysial line, approximately disposed in three transverse, subparallel rows; anterior row (AR) with three long setae, four short setae and five pits; middle row (MR) relatively confused, with seven long setae; posterior row (PR) with five long setae, one short seta and one pit; prosternum not sclerotized, sterna of meso- and metathorax slightly sclerotized medially; prosternum with three pairs of small setae longitudinally, arranged medially (two anterior pairs and a long one between procoxae), with two pairs of short setae on external of coxae. Mesonotum three times as wide as long, with nine long setae in three rows on each side: AR with one minute seta, one short seta and one pit; MR with five setae; PR with four setae and two pits; mesosternum with two pairs of small setae longitudinally, arranged medially (anterior one short and posterior one long), and one pair of short setae on external of coxae. Setae of metathorax similar in number, position and relative size as those on mesothorax, except only with one pair of minute setae on AR of metanotum.

Legs (Fig. 2b): Coxae short and broad, obliquely truncate and unsclerotized at apex, with four subapical setae, two minute setae and two pits; trochanters without setae basally but with medial belt of six or seven pits and two setae; femora slightly enlarged from base to apex, slightly compressed laterally; profemur shorter than others, meso- and metafemora similar in length; femora each with 12 setae and one pit, major ventral femoral seta much shorter than femur, and increasing in length from pro- to metafemora; tibiotarsi and claws increasing in length and nar- 


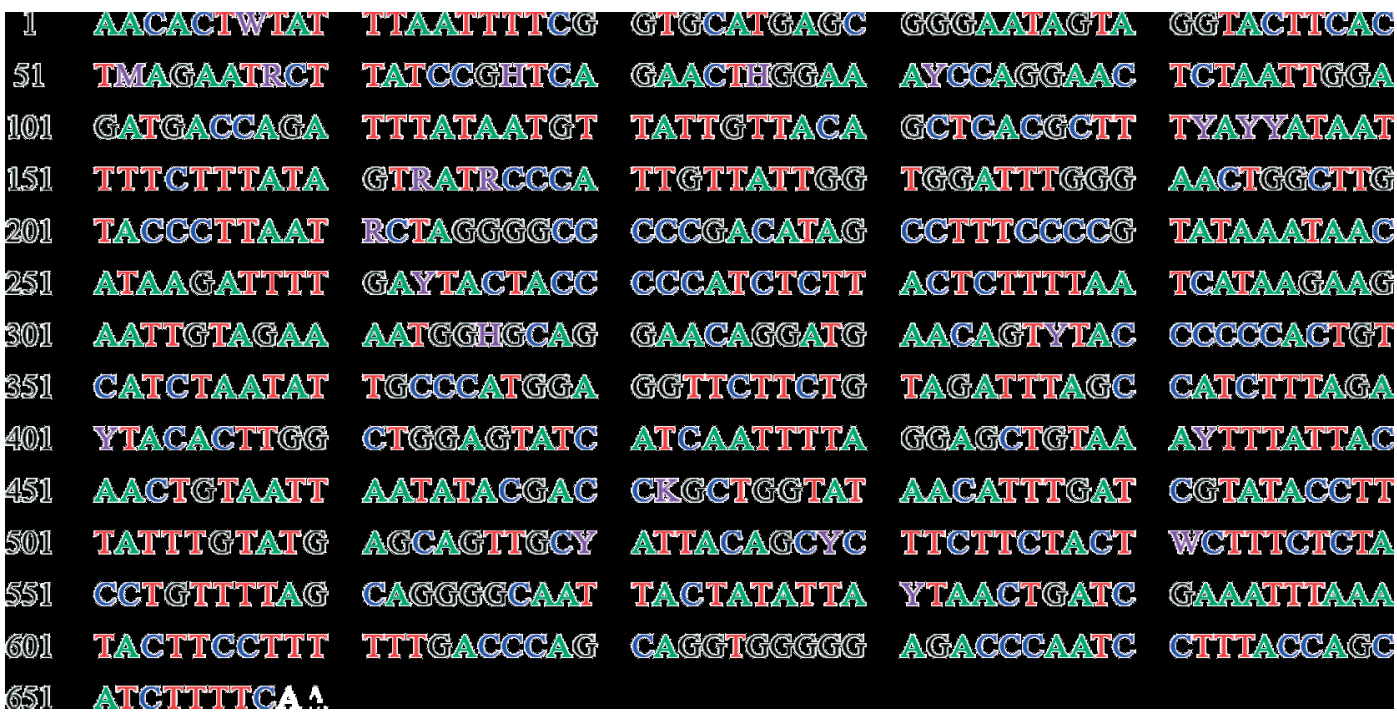

Fig. 3. COI sequences for DNA barcodes from 19 individuals of Hycleus solonicus. Codes for variable sites (for frequencies, see Table 2): M: A or C, R: A or G, W: A or T, Y: C or T, K: G or T, and H: A or C or T (according to The International Union of Pure and Applied Chemistry, IUPAC).

rowing from pro- to metathorax; tibiotarsi with four longitudinal rows of 3-5 robust setae; claws (Fig. 2g) thin, acute and slightly curved at apex, with 2 sub-basal setae of different length, slightly displaced at base, distal seta nearly twice longer than proximal one and almost approaching apex.

Abdomen (Fig. 2a, b): Gradually tapering from base to apex, maximum width at segment I; terga rectangular with entire posterior margins; laterotergites completely fused with medial terga; terga of segments I-VIII with three transverse rows of setae, each lateral half with setation as follows: AR with one minute seta (three on tergum I) and one pit, MR with three short setae and PR with five long setae and one pit; tergum IX with ten setae in two rows (four on AR and six on PR), and two very elongate caudal setae on apical margin, about as long as distance from anterior margin of mesonotum to posterior margin of abdominal tergum IX. Sterna well sclerotized, entire, subrectangular; setation of sterna as follows: AR and MR with one pair of short setae, PR with three pairs of long setae forming a row along posterior margin of sclerites; PR of sternum IX with two pairs of short setae. Abdominal apex (segment X or pygopod) membranous.

Spiracles: Single mesothoracic spiracle (Fig. $2 \mathrm{~h}$ ) ventrolateral in position; abdominal spiracles I-VIII open, similar in size and shape, slightly smaller than mesothoracic spiracle, placed on posterior part of laterotergites.

\subsection{DNA barcoding}

Nineteen mitochondrial COI sequences of $\mathrm{H}$. solonicus were obtained in total. They were pruned to lengths of 658 bp (Fig. 3) after sequence alignment and the manual removal of low quality sections. In its nucleotide composition, A, T, C and G are $27.8 \%, 34.4 \%, 20.6 \%$ and $17.2 \%$ respectively, where $\mathrm{A}+\mathrm{T}$ content $(62.2 \%)$ is higher than $\mathrm{C}+\mathrm{G}$ content $(37.8 \%)$. There were 636 conservative sites and 22 variable sites, the latter ones are listed in Table 2. No frame shift or nonsense codons were found.

The mean intraspecific genetic distance in $H$. solonicus was 0.005 , and the mean interspecific genetic distance values between the pairs of two species are listed in Table 3. The interspecific genetic distance between $H$. solonicus and $H$. chodschenticus was 0.004 , subequal to the intraspecific genetic distance in $H$. solonicus. After checking the GenBank sample information of the H. chodschenticus sequence JX679716, we believe that the submitter of that sequence probably determined the species incorrectly. 
Table 2. Variable sites and probabilities of each base in the $19 \mathrm{COI}$ sequences of Hycleus solonicus.

\begin{tabular}{rcccc}
\hline Sites & A $(\%)$ & $T(\%)$ & $C(\%)$ & $G(\%)$ \\
\hline 7 & 5.9 & 94.1 & - & - \\
52 & 66.7 & - & 33.3 & - \\
58 & 94.4 & - & - & 5.6 \\
67 & 5.6 & 11.1 & 83.3 & - \\
76 & 16.7 & 11.1 & 72.2 & - \\
82 & - & 94.4 & 5.6 & - \\
142 & - & 61.1 & 38.9 & - \\
144 & - & 94.4 & 5.6 & - \\
145 & - & 94.4 & 5.6 & - \\
163 & 38.9 & - & - & 61.1 \\
166 & 83.3 & - & - & 16.7 \\
211 & 73.7 & - & - & 26.3 \\
263 & - & 94.4 & 5.6 & - \\
316 & 89.4 & 5.3 & 5.3 & - \\
337 & - & 5.3 & 94.7 & - \\
401 & - & 21.1 & 78.9 & - \\
442 & - & 5.3 & 94.7 & - \\
472 & - & 94.7 & - & 5.3 \\
520 & - & 5.3 & 94.7 & - \\
529 & - & 78.9 & 21.1 & - \\
541 & 15.8 & 84.2 & - & - \\
581 & - & 94.7 & 5.3 & - \\
& & & &
\end{tabular}

\subsection{Bionomics of adults}

\subsubsection{Phenology}

Adults are active in spring and summer, from April to August, but mainly in the early and middle of July (records of the early and middle July represent $45.45 \%$ of the total records, specimens of IZCAS, MHBU, MHBUa, NKUM, NXU, TMNH, Reichardt 1934, Kôno 1940, Pan et al. 2010, 2011a, 2013).

\subsubsection{Host plants}

The known host plants of $H$. solonicus are: Amaranthaceae: Beta vulgaris (Zhao et al. 2012),
Convolvulaceae: Convolvulus arvensis (Peng, see in Acknowledgements), Leguminosae (Tan 1986, Guo 1994, Hua 2002): Astragalus propinquus (Tan 1986, Guo 1994), Glycine max (Zhao et al. 2012), Phaseolus vulgaris (Zhao et al. 2012), Paeoniaceae: Paeonia lactiflora (Guo 1994), Solanaceae: Solanum tuberosum (Zhao et al. 2012), and Theaceae: Camellia oleifera (Zhao et al. 2012).

\subsection{Distribution}

Hycleus solonicus is distributed in China (Northern, Northeastern and Central territories), Kazakhstan, Korea, Mongolia (Eastern, Central and Northern territories), and Russia (Siberia, Far East). Records of elevation are from 350 to 1,296 $m$ a.s.1. (specimens of IZCAS, MHBU, MHBUa, NKUM).

\section{Discussion}

According to the previous literature, Zonabris solonica var. dianae Sahlberg, 1913 is a variety of the species H. solonicus (Sahlberg 1913, Sumakov 1930, Bologna 2008, Pan et al. 2011a). We examined a possible type specimen (female) borrowed from the MZH which had been collected from the type locality [Ephesus of Turkey ("Ephesi")] and determined by Sahlberg, but the type label is absent. We found that Zonabris solonica var. dianae conspicuously differs from $H$. solonicus. Therefore, Z. solonica var. dianae remains in the polymorphus group but must be referred to a species other than H. solonicus. We propose that $Z$. solonica var. dianae could be a synonym of Hycleus scabiosae (Olivier, 1811).

Because of incorrect determinations of $H$. solonicus, e. g. as Mylabris axillaris Billberg,

Table 3. Pairwise distances between five species of Hycleus based on COI sequences.

\begin{tabular}{lcccc}
\hline & H. solonicus & H. chodschenticus & H. phaleratus & H. cichorii \\
H. solonicus & & & & \\
H. chodschenticus & 0.004 & 0.182 & & \\
H. phaleratus & 0.181 & 0.186 & 0.108 & \\
H. cichorii & 0.184 & 0.107 & 0.198 & 0.173 \\
H. parvulus & 0.105 & & \\
\hline
\end{tabular}


1813 by Tan (1986) and as H. chodschenticus (Ballion, 1878) by Pan et al. (2011), the geographic distribution of $H$. solonicus is poorly defined. According to the present study, there are some doubtful collection localities in the literature:

1) Specimens collected in Jiangxi Province (Pan et al. 2011a, 2011b, 2013, Zhao et al. 2012) should be listed from Jiangsu Province. These errors are due to orthographic mistakes;

2) The Turkish locality of "Ephesi" recorded by Sahlberg (1913) is the type locality of Zonabris solonica var. dianae, then referred by Sumakov (1930) as Turkish European territory. After removing this variety (see above), we confirm that $H$. solonicus does not occur in W Turkey;

3) Altai (Kuzin 1954), Georgia (Reiche 1865, Sumakov 1930), "Asia Minor" (Sumakov 1930), "Turkestan" (Heyden 1893, Sumakov $1915,1930)$ are various localities recorded in older literature. Some of them could refer to other species, which are quite similar to $H$. solonicus, such as $H$. humerosus. Therefore, the validity of these localities needs further verification;

4) The following localities are recorded for $H$. chodschenticus (Pan et al. 2010 2011a, 2011b, 2013, Zhao et al. 2012): Azerbaijan, Kyrgyzstan, Uzbekistan, Tajikistan, and Turkmenistan. These records probably refer to the true H. chodschenticus (Ballion, 1878);

5) Egypt and Syria represent the distribution of $M$. axillaris Billberg, but they were incorrectly recorded by Tan (1986) and Hua (2002).

Acknowledgements. We wish to thank the following curators or entomologists attached to Museums, for permission to study the Meloidae preserved in their institutions or private collections, and for their helpful support: Dr. HongBin Liang (IZCAS), Dr. Jaakko Mattila (MZH), Prof. GuoQing Liu (NKUM), Prof. Xin-Pu Wang (NXUM), and Dr. Shu-Lian Hao (TMNH). In particular we are grateful to Prof. Marco A. Bologna (University of "Roma Tre", Rome, Italy) for providing localities information of $H$. solonicus from his collections. Thanks to Mr. Zhi-Zhong Gao (Hebei University, Baoding, China) who collected the materials from the field which were useful for the larval morphological study, and to Mr. Bo Peng (Municipal Bureau of Landscape and Forestry of Xicheng District,
Beijing, China) who provided an identification of a certain host plant. Finally thanks to Dr. Jomo Macdermott (USA) for the English revision.

Financial support for sampling and sequencing analyses of this paper came from Special Project for Science and Technology Basic Work from Ministry of Science and Technology (No. 2012FY111100), The Construction Foundation for Comprehensive Strength Promotion of Universities in Mid-western China to Hebei University, The Postdoctoral Research Foundation of Hebei Province (No. B2015003007), Scientific Research Project of Colleges and Universities in Hebei Province, Youth Program (No. QN2016067), The Key Laboratory of Zoological Systematics and Application (No. 14967611D), which are gratefully acknowledged.

\section{References}

Beauregard, H. 1890: Les insectes vésicants. — Félix Alcan, Paris. xvi +544 pp., 34 pls.

Billberg, G. J. 1813: Monographia Mylabridum. — Caroli Delén, Holmiae. $74+6$ pp., 7 pls.

Bologna, M. A. 1978: Alcuni Meloidi dell'Africa orientale e meridionale e descrizione di una specie nuova (Coleoptera, Meloidae). - Quaderni dell'Accademia nazionale dei Lincei, Roma 243: 137-189.

Bologna, M. A. 1979: Meloidae di Turchia. I contributo. - Fragmenta Entomologica 15: 143-199.

Bologna, M. A. 1990: Faunistica e zoogeografia dei Meloidae (Coleoptera) della Somalia. - Biogeographia (NS) 14: 293-401.

Bologna, M. A. 1991: Coleoptera Meloidae. Fauna d'Italia. XXVIII. - Calderini, Bologna. XIV + 541 pp.

Bologna, M. A. 2008: Family Meloidae Gyllenhal, 1810. — In: Löbl, I. \& Smetana, A. (eds), Catalogue of Palaearctic Coleoptera (Vol. 5: Tenebrionoidea): 370 412. Apollo Books, Stenstrup. 670 pp.

Bologna, M. A. \& Pinto, J. D. 2001: Phylogenetic studies of Meloidae (Coleoptera), with emphasis on the evolution of phoresy. - Systematic Entomology 26: 33-72. http://dx.doi.org/10.1046/j.1365-3113.2001.00132.x

Bologna, M. A. \& Pinto, J. D. 2002: The Old World genera of Meloidae (Coleoptera): a key and synopsis. - Journal of Natural History 36: 2013-2102.

Bologna, M. A. \& Turco, F. 2007: The Meloidae (Coleoptera) of the United Arab Emirates with an updated Arabian checklist. - Zootaxa 1625: 1-33.

Dokhtouroff, W. 1889: Faune coléoptérologique aralo-caspienne. XIII partie. Meloïdes et cantharides (Mlabrides). - Horae Societatis Entomologicae Rossicae 24: 121-192, pl. 121.

Escherich, K. L. 1892: Uber die Gesetzmäfsigkeit im Abändern der Zeichnung bei Insecten. - Deutsche Entomologische Zeitschrift 1892: 113-130, pl. 111.

Escherich, K. L. 1899: Zur kenntniss der Coleopteren-Gattung Zonabris Harold. - Wiener Entomologische Zeitung 18: 84-92, 97-109.

Fischer, J. B. 1827: Tentamen conspectus Cantharidiarum. Dissertatio inauguralis quam pro summis in medicina 
et chirurgia honoribus legitime obtinendis eruditorum examini. - Lindauer, Monachi. 26 pp.

Gemminger, M. \& Harold, E. von 1870: Familia LX. Cantharidae. - In: Gemminger, M. \& Harold, E. von (eds), Catalogus coleopterorum hucusque descriptorum synonymicus et systematicus. Tom. VII. Tenebrionidae, Nilionidae, Pythidae, Melandryidae, Lagriidae, Pedilidae, Anthicidae, Pyrochroidae, Mordellidae, Rhipidophoridae, Cantharidae, Oedemeridae: 2124-2164. E. H. Gummi, Monachii. 2179 + 10 pp.

Guo, Y. C. 1994: (The species and distribution of Meloidae from Inner Mongolia.) - Inner Mongolia Agricultural Science and Technology 1: 4, 22. [In Chinese.]

Heyden, L. F. J. D. von 1881: Catalog der Coleopteren von Sibirien mit Einschluss derjenigen der Turanischen Länder, Turkestans und der chinesischen Grenzgebiete. - A. W. Schade's Buchdrnekerei, Berlin. 224 pp.

Heyden, L. F. J. D. von 1893: Catalog der Coleopteren von Sibirien, mit Einschluss derjenigen des östlichen Caspi-Gebietes, von Turcmenien, Turkestan, Nord-Thibet und des Amur-Gebietes. Mite specieller Angabe der eiuzeluen Fundorte und genauer Citirung der darauf bezüglichen Literatur. Nachtrag I. - A. W. Schade's Buchdruckerei, Berlin. 217 pp.

Hua, L. Z. 2002: Meloidae. - In: Hua, L. Z. (ed.), List of Chinese insects (Vol. II): 129-131. Zhongshan (San Yat-sen) University Press, Guangzhou. 612 pp.

Iablokoff-Khnzorian, S. M. 1983: (Fauna Armenia. Vol. 5. Coleoptera, Meloidae \& Alleculidae.) - Akademia Nauk Armyanskoy SSR, Erevan. 155 pp. [In Russian.]

Juchnevitsh, L. A. 1955: (Observations on the biology of the meloid genus Mylabris F. in Kazakhstan.) - Trudy Instituta Zoologii Akademii Nauk Gruzinskoi SSR 4: 173-198. [In Russian.]

Kôno, H. 1940: Die Meloiden von Mandschukuo. — Insecta Matsumurana 15: 57-62.

Kimura, M. 1980: A simple method for estimating evolutionary rates of base substitutions through comparative studies of nucleotide sequences. - Journal of Molecular Evolution 16: 111-120.

Kuzin, V. S. 1954: (The knowledge of the blister beetle system (Coleoptera, Meloidae, Mylabrini).) — Trudy Vsesoyznogo Entomologicheskogo Obshchestva 44: 336-379. [In Russian.]

Liu, S. P., Pan, Z. \& Ren, G. D. 2016: Identification of three morphologically indistinguishable Epicauta species (Coleoptera, Meloidae, Epicautini) through DNA barcodes and morphological comparisons. - Zootaxa 4103: 361-373. http://doi.org/10.11646/zootaxa. 4103.4.4

Ménétriés, E. 1854: Coléoptères recueillis dans la Mongolie chinoise et aux environs de Pékin. - Études Entomologiques 3: 26-41.

Ma, Y., Li, H. C. \& Kang, L. 1991: Meloidae. — In: Ma, Y., Li, H. C. \& Kang, L. (eds.), The grassland insects of Inner Mongolia: 148-149. Tianze Eldonejo, Yangling. 467 pp. [In Chinese.]

MacSwain, J. W. 1956: A classification of the first instar larvae of the Meloidae (Coleoptera). - University of California Press, Berkeley. 182 pp.
Marseul, S. A. de 1870: Monographie des Mylabrides d'Europe, et des contrées limitrophes en Afrique et en Asie. — L'Abeille 7: 1-204.

Marseul, S. A. de 1872: Monographie des Mylabrides. Mémoires de la Société royale des Sciences de Liège: 363-662, 369 pls.

Oertzen, E. von 1886: Verzeichniss der Coleopteren Griechenlands und Cretas, nebst einigen Bemerkungen über ihre geographische Verbreitung und 4 die Zeit des Vorkommens einiger Arten betreffenden Sammelberichten. - Berliner Entomologische Zeitschrift 30: 189-293.

Pallas, P. S. 1782: Icones Insectorum praesertim Rossiae Sibiriaeque peculiarum quae collegit et descritionibus illustravit. Fasciculus secundus. (Descriptions and illustrations of insects in personal collections from Russian Siberia. Volume 2) - W. Waltheri, Erlangae. 57-96 \& plates A-F.

Pan, Z., Carosi, M. \& Bologna, M. A. 2014: A new Eastern Asian Hycleus and key to the Chinese species of the phaleratus group (Coleoptera, Meloidae, Mylabrini). - ZooKeys 463: 11-19.

Pan, Z., Ren, G. D. \& Wang, X. P. 2011a: Taxonomy of the genus Hycleus Latreille (Coleoptera, Meloidae) from China, with description of one new species. - Acta Zootaxonomica Sinica 36: 179-197. [In Chinese with English summary.]

Pan, Z., Ren, G. D., Li, Y. L., Li, X. M. \& Wang, X. P. 2011b: Taxonomic notes on species of blister beetles (Coleoptera: Meloidae) from Hebei Province. - Sichuan Journal of Zoology 30: 728-730, 733. DOI: 10.3969/j.issn.1000-7083.2011.05.011. [In Chinese with English summary.]

Pan, Z., Wang, X. P. \& Ren, G. D. 2010: Meloidae. — In: Ren, G. D. (ed.), Fauna of Invertebrata from Liupan Mountain: 184-187. Press of Hebei University, Baoding. 683 pp. +6 pls. [In Chinese.]

Pan, Z., Wang, X. P. \& Ren, G. D. 2013: Meloidae. - In: Ren, G. D., Guo, S. B. \& Zhang, F. (eds.), Fauna of Insects from Xiaowutai Mountain: 212-217 (chapter 130). Press of Hebei University, Baoding. 738 pp. [In Chinese.]

Pardo Alcaide, A. 1954: Études sur les Meloidae V. Les Mylabrini du Maroc et du Sahara occidental espagnol (Col. Meloidae). - Bulletin de la Société des Sciences Naturelles et Physiques du Maroc 34: 55-88.

Pardo Alcaide, A. 1955: Estudios sobre Meloidae VI. Sobre algunos Mylabris (s. lat.) de la región etiópica. Bulletin de l'Institut Royal de Sciences Naturelles de Belgique 31: 1-32.

Pardo Alcaide, A. 1958: Etudes sur les Meloidae (Col.). IC. Observations sur quelques Mylabris $(s$. l.) des régions éthiopienne et orientale. - Bulletin de l'Institut Royal de Sciences Naturelles de Belgique 34: 1-39.

Pardo Alcaide, A. 1968: Étude sur les Meloidae (Coleoptera). XX. Sur le genre Gorrizia Pardo et une nouvelle espèce soudanaise du groupe du brunnipes (Klug). EOS, Revista Española de Entomologia 43: 623-629.

Priamikova, M. A. \& Juchnevitsh, L. A. 1958: Key to triungulins of blister-beetles (Coleoptera, Meloidae) 
of the tribe Mylabrini of the fauna of the USSR. - Revue d'Entomologie de l'URSS 37: 176-181. [In Russian.]

Reichardt, A. N. 1934: (Qualifier and list of Meloidae beetles from Turkmenistan.) - Trudy Sovet po izucheniiu proizvoditel'nykh cil SSR. Seriia turkmenskaia 6: 205-239. [In Russian.]

Reiche, L. J. 1866: Étude sur les epèces de mylabrides de la collection de L. Reiche, suivie d'une note sur le genre Trigonurus Mulsant et description d'une espèce nouvelle. - Annales de la Société Entomologique de France (ser. 4) 5 [1865]: 627-642.

Ren, G. D. \& Niu, Y. P. 2011: Phylogenetic analysis of Chinese meloid beetles (Coleoptera, Tenebrionoidea) at the tribal level based on characters of the hind wing. Acta Zootaxonomica Sinica 36: 136-143. [In Chinese with English summary.]

Saha, G. N. 1972: Observations on a collection of blister beetles, Mylabris Fabricius (Coleoptera: Melidae), from Pakistan, with the description of a new species and a new subspecies. - Proceedings of the Zoological Society Calcutta 25: 19-23.

Saha, G. N. 1979: Revision of Indian blister beetles (Coleoptera: Meloidae: Meloinae). - Records of the Zoological Survey of India 74: 1-146.

Sahlberg, J. R. 1913: Coleoptera mediterranea orientalis quae in Aegypto, Palestina, Syria, Caramania collegerunt John Sahlberg et Unio Saalas. — Öfversigt af Finska Vetenskaps-Societetens Förhandlingar 55: 1282.

Schoenherr, C. J. 1817: Synonymia Insectorum, oder: Versuch einer Synonymie aller bisher bekannten Insecten; nach Fabricii Systema Eleutheratorum geordnet. Er- ster Band. Eleutherata oder Käfer. Dritter Theil. Hispa-Molorchus. - Em. Bruzelius, Uppsala. xi +506 pp.

Sumakov, G. G. 1915: Les espèces paléarctiques du genre Mylabris Fabr. (Coleoptera, Meloidae). - Horae Societatis Entomologicae Rossicae 42: 1-71.

Sumakov, G. G. 1930: Catalogue des espèces paléarctiques de tribu Mylabrina (Coleoptera, Meloidae). — Acta Instituti et Musei Zoologici Universitatis Tartuensis 37: $1-114$.

Tan, J. J. 1986: Meloidae. — In: Institute of Zoology, Academia Sinica (ed.), (Agricultural Insects of China) (Vol. I): 483-487. Agricultural Publishing House, Beijing. 766 pp. [In Chinese.]

Tan, J. J., Zhang, Y. W., Wang, S. Y., Deng, Z. J. \& Zhu, C. $X .1995$ : Investigation on the natural resources and utilization of the Chinese medicinal beetles - Meloidae. - Acta Entomologica Sinica 38: 324-331. [In Chinese with English summary.]

Tshernyshev, S. E. \& Axentiev, S. I. 1996: Blister beetles (Coleoptera, Meloidae) of Mongolia. - Russian Entomological Journal 5: 49-57.

Waltl, de P. 1838: Matériaux pour servir a l'étude des coléoptères de Turquie. - Isis von Oken 31: 449-472.

Yang, Y. X. \& Ren, G. D. 2007: Hind-wing morphology of Mylabris Fabricius (Coleoptera: Meloidae) from China. - Acta Entomologica Sinica 50: 429-434. [In Chinese with English summary.]

Zhao, Y. N., He, H. M. \& Wang, X. P. 2012: Species of blister beetles in Ningxia (Coleoptera, Meloidae). - Journal of Agricultural Sciences 33: 35-39. [In Chinese with English summary.] 
Appendix I. Sample data for molecular analysis of Hycleus solonicus.

\begin{tabular}{lll}
\hline Codes & Localities & Date \\
\hline 140728-140732, 140915, & Agriculture, forestry and orchard, Mt. Xiaowutaishan, & 5. VII.2014 \\
$140916,140919,140922$ & Hebei Prov., China & \\
$140739-140742,140921$ & Zhangjiayao, Mt. Xiaowutaishan, Hebei Prov., China & 2. VII.2014 \\
140971 & Shanjiankou, Mt. Xiaowutaishan, Hebei Prov., China & 30. VI.2014 \\
141214,141217 & Mt. Xiaowutaishan, Yu County, Hebei Prov., China & 5. VII.2014 \\
32JH3 & Huangtuliang, Pingquan County, Hebei Prov., China & 3. VIII.2012 \\
M1H5 & Bashihao, Dahuanqi, Saihanba, Weichang County, & 1. VI.2015 \\
& Hebei Prov., China & \\
\hline
\end{tabular}

Appendix II. List of localities from literature and museum collections (for abbreviations of museums, see Materials and methods).

China. China (Tshernyshev \& Axentiev 1996); China border (Gemminger \& Harold 1870); Man Choei (TMNH); Mao eull chan (TMNH); Si chan (TMNH); Chan si S. O. (TMNH). Beijing (Tan 1986, Pan et al. 2010, 2011a, 2011b, 2013, Zhao et al. 2012): Badaling (MAB). Gansu (Pan et al. 2010, 2011a, 2011b, 2013, Zhao et al. 2012): Heshui County: Taibai (MHBU). Hebei (Tan 1986, Hua 2002, Pan et al. 2010, Zhao et al. 2012): Beidaihe City (NKUM, Pan et al. 2011b); Fengning County (Pan et al. 2011b): Dengzhazi Forest Farm (MHBU, Pan et al. 2011a); Fuping County (Pan et al. 2011b): Longquanguan (MHBU); Laiyuan County (Pan et al. 2011b): Mt. Baishishan (MHBU, Pan et al. 2011a), Mt. Hushan (MHBU, Pan et al. 2011a); Longhua County (MHBU, Pan et al. 2011b); Pingquan County: Huangtuliang (MHBUa); Weichang County (MHBU, Pan et al. 2011b): Kelegou, N

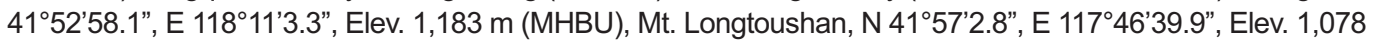

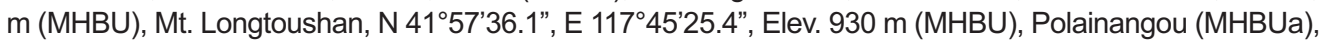
Saihanba (MHBU): Bashihao, Dahuanqi (MHBUa), Wudaogou, N 42¹'3.3”, E 11658'54.1', Elev. 1,111 m (MHBU), Yudaokou (MHBU), Zhongmiaochang, N 42 5'34.9”, E 117²5'5.5”, Elev. 1,288 m (MHBU); Yu County (Pan et al. 2011b): Mt. Xiaowutaishan (MHBU, MHBUa, Ren \& Niu 2011, Pan et al. 2011a, 2013), Chiyapu (MHBU, Pan et al. 2011a, 2013), Jinhekou (MHBU, Pan et al. 2011a, 2013), Wangxidong (MHBU, Pan et al. 2013), Zhangjiayao (MHBUa); Zhangbei County (MHBU, Yang \& Ren 2007, Pan et al. 2011b); Zhuolu County (Pan et al. 2011b): Chadao Forest Farm (MHBU), Shanjiankou (MHBU, MHBUa, Pan et al. 2011a, 2013), Yangjiaping Forest Farm (MHBU, Pan et al. 2013). Heilongjiang (Bolonga 2008, Pan et al. 2010, 2013, Zhao et al. 2012): Ning'an County: Jingpo Lake (NKUM); Xi'an District (Kôno 1940). Hubei (Tan 1986, Hua 2002, Pan et al. 2010, 2011a, 2011b, 2013, Zhao et al. 2012). Hunan (Pan et al. 2010, 2011b, 2013, Zhao et al. 2012): Fenghuang County (MHBU, Pan et al. 2011a). Inner Mongolia (Tan 1986, Guo 1994, Hua 2002, Pan et al. 2010, 2011b, 2013, Zhao et al. 2012): Chifeng City (Tan et al. 1995); Fengzhen City (MHBU); Hexigten Banner: Beijingzi (MHBU), Mt. Junzishan (MHBU); Hohhot City: Mt. Daqingshan (MHBU); Horqin Right Wing Front Banner (Ma et al. 1991); Horqin Right Wing Middle Banner (Ma et al. 1991); Huade County (MHBU); Jalaid Banner (Ma et al. 1991); Jungar Banner: Dafanpu (MHBU), Shierliancheng (MHBU); Liangcheng County (MHBU, Pan et al. 2011a): Erlongshitai (MHBU); Wuchuan County: Shuangyucheng (MHBU). Jiangsu (Tan 1986, Hua 2002, Pan et al. 2010). Jiangxi: should be Jiangsu (Pan et al. 2011a, 2011b, 2013, Zhao et al. 2012). Liaoning: Tieling (Kôno 1940): Kaiyuan (Kôno 1940); Môkasai (Kôno 1940). Ningxia (Pan et al. 2011b, 2013): Guyuan County: Kaicheng (MHBU, Pan et al. 2010, 2011a), Woyangchuan (MHBU, Pan et al. 2010, 2011a), Yunwushan (NXUM); Jingyuan County: Erlong River (MHBU, Pan et al. 2010, 2011a), Qiuqianjia (MHBU, Pan et al. 2010, 2011a), Xixia (MHBU, Pan et al. 2010, 2011a); Mt. Liupanshan (Zhao et al. 2012); Pengyang County: Guamagou (MHBU, Pan et al. 2010, 2011a). Shaanxi (Pan et al. 2010, 2011b, 2013, Zhao et al. 2012): Yan'an City (MHBU, 
Pan et al. 2011a). Shanxi (Pan et al. 2010, 2011b, 2013, Zhao et al. 2012): Mt. Lishan (MHBU); Datong City (MHBU, Pan et al. 2011a): Yungang (MHBU); Fanshi County (MHBU, Pan et al. 2011a); Hunyuan County: Mt. Hengshan (MHBU, Pan et al. 2011a); Ningwu County: Mt. Luyashan (MHBU); Pinglu District (MHBU). Xinjiang (Tan 1986, Hua 2002, Pan et al. 2010, 2011a, 2011b, 2013, Zhao et al. 2012): Tacheng County (Tan et al. 1995), Yining County: Qingshuihe (NXUM).

Kazakhstan. Kazakhstan (MAB).

Korea. Korea (Kôno 1940, Tshernyshev \& Axentiev 1996, Bologna 2008).

Mongolia. Mongolia (Bologna 2008). N Mongolia (Kuzin 1954); NE Mongolia (Tshernyshev \& Axentiev 1996); Bulgan: Selenge, N 49.46 ${ }^{\circ}$, E 104.29 ${ }^{\circ}$, Elev. 771-807 m (IZCAS). Dornod: Khalhgol, N 47.66048 ${ }^{\circ}$, E

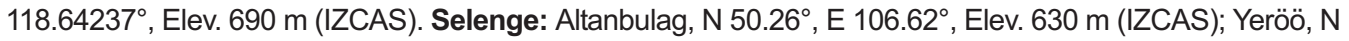

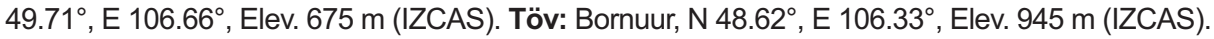

Russia. Southern territory (Schoenherr 1817, Fischer 1827, Gemminger \& Harold 1870). Siberia (Sumakov 1915, Kôno 1940): East Siberia (lablokoff-Khnzorian 1983, Bologna 2008): Dauria (Marseul 1872, Sumakov 1930), Irkutsk (Sumakov 1930), Transbaikalia (Kuzin 1954, Tshernyshev \& Axentiev 1996); West Siberia (Bologna 2008). Far East (Tshernyshev \& Axentiev 1996, Bologna 2008): 20 km SW Putylaska (MAB). Caucasus (Escherich 1892).

"Central asia" (lablokoff-Khnzorian 1983).

"Turkestan". Turkestan (Doktouroff 1889, Heyden 1893, Sumakov 1915, 1930, Kôno 1940).

Doubtful localities. Georgia (Reiche 1865, Sumakov 1930). Russia: Altai (Kuzin 1954). "Asia Minor” (Sumakov 1930). "Griechenland” (= Greece) (Kôno 1940).

Incorrect records. Azerbaijan, Kyrgyzstan, Uzbekistan, Tajikistan, Turkmenistan (Pan et al. 2010, 2011a, 2011b, 2013, Zhao et al. 2012). Egypt, Syria (Tan 1986, Hua 2002). Turkey: European Territory (Sumakov 1930): Izmir: Ephesus (Sahlberg 1813). 